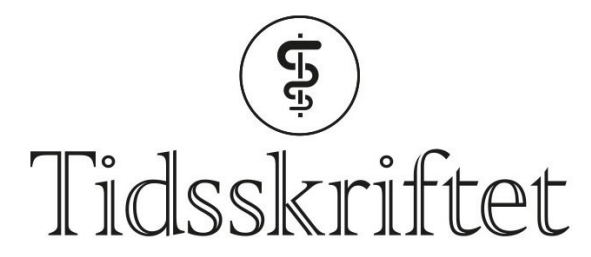

DEN NORSKE LEGEFORENING

\title{
Nye legemidler er ofte ikke bedre
}

FRA ANDRE TIDSSKRIFTER

KETIL SLAGSTAD

Institutt for helse og samfunn

Universitetet i Oslo

Over halvparten av nye legemidler godkjent for bruk i Tyskland har ingen tilleggseffekt sammenliknet med allerede tilgjengelige legemidler.

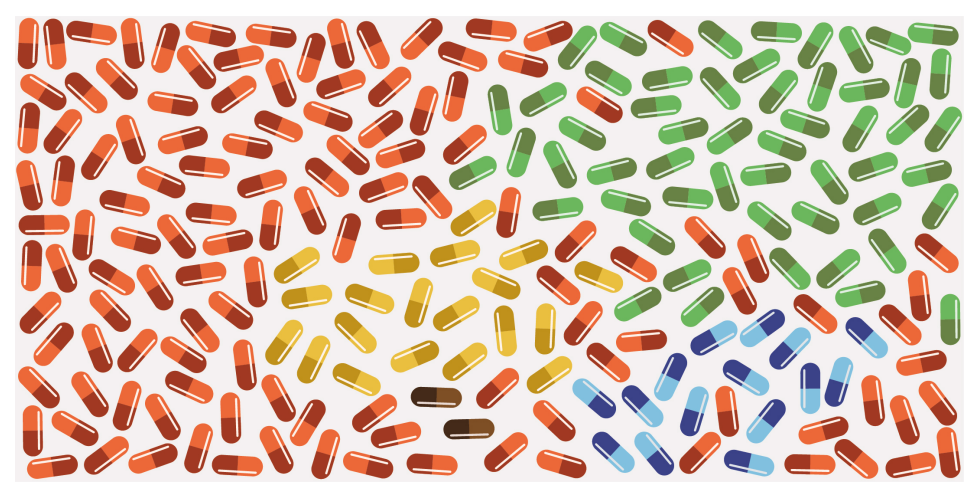

Tall fra tysk studie der nye godkjente legemidlers effekt sammenliknes med tilgjengelige legemidler: Av 216 medisiner hadde 125 ingen tilleggseffekt (rødt), 54 hadde betydelig tilleggseffekt (grønt), 20 hadde liten tilleggseffekt (gult), 20 var ikke-kvantifiserbare (blått) og 2 hadde mindre effect (brunt). Illustrasjon: Tidsskriftet

Kun halvparten av nye kreftlegemidler godkjent av europeiske legemiddelmyndigheter har dokumentert effekt på pasienters overlevelse eller livskvalitet (1). Nå viser en ny studie publisert i tidsskriftet BMJ at mer enn halvparten av nye legemidler godkjent av tyske myndigheter ikke hadde noen tilleggseffekt sammenliknet med andre tilgjengelige legemidler (2).

Når nye legemidler blir godkjent for det tyske markedet, må legemiddelfirmaet sende inn en rapport om legemiddelets effekt sammenliknet med tilgjengelige legemidler. Et offentlig utvalg beslutter deretter om legemiddelet har $\emptyset \mathrm{kt}$ nytteverdi eller ikke. Av 216 legemidler som ble godkjent i perioden 2011-17, hadde mer enn halvparten ingen tilleggseffekt sammenliknet med standard behandling. Kun én firedel av legemidlene hadde betydelig tilleggseffekt. Resultatene var spesielt nedslående for legemidler innen psykiatri/nevrologi og mot diabetes, der tilleggseffekt ble påvist i bare $6 \%$ og $17 \%$ av de godkjente legemidlene.

I mange tilfeller finnes det ikke forskning som kan si sikkert om nye legemidler er bedre eller dårligere enn tilgjengelig behandling. Oppfølgingsstudier etter godkjenning blir ofte ikke gjennomført. Forskerne bak studien foreslår at godkjenning av nye legemidler først 
kan gis basert på studier der legemidlene sammenliknes med allerede tilgjengelige legemidler og på gode langtidsstudier. De etterlyser en mer aktiv legemiddelpolitikk der legemidler utvikles først og fremst for å dekke pasienters og samfunnets behov og ikke legemiddelfirmaenes ønske om profitt.

\section{LITTERATUR:}

1. Slagstad K. Bare halvparten av nye, godkjente kreftlegemidler har dokumentert effekt. Tidsskr Nor Legeforen 2018; 138. doi: 10.4045/tidsskr.18.0024. [PubMed][CrossRef]

2. Wieseler B, McGauran N, Kaiser T. New drugs: where did we go wrong and what can we do better? BMJ 2019; 366: 14340. [PubMed][CrossRef]

Publisert: 16. september 2019. Tidsskr Nor Legeforen. DOI: 10.4045/tidsskr.19.0477

(C) Tidsskrift for Den norske legeforening 2020. Lastet ned fra tidsskriftet.no 